\title{
Assessing different chemoprophylactic protocols against bovine tick- borne diseases and their influence on the weight gain of calves
}

\section{Avaliação de diferentes protocolos de quimioprofilaxia da Tristeza Parasitária Bovina sobre o ganho de peso de novilhos}

\author{
Sergio Silva da Silva ${ }^{1 *}$; Iuri Vladimir Pioly Marmitt²; Samuel Rodrigues Felix ${ }^{2}$; \\ Daniela Miyasaka Silveira ${ }^{3}$ Cassol; Marcus Luciano Gumarães Rezende 3 ; Éverton \\ Fagonde da Silva ${ }^{1}$; Mario Carlos Araújo Meireles ${ }^{1}$; Leandro Quintana Nizoli ${ }^{1}$
}

\begin{abstract}
In the present study, 87 Aberdeen Angus calves were used to assess the effects of low dose, agentspecific drugs on weight gain after a babesiosis and anaplasmosis outbreak. All animals were weighed on weaning (day -34) and again on day zero, with a mean (on day zero) of $223.46 \mathrm{Kg}$ and an average individual daily weight gain (ADG) of $0.258 \mathrm{Kg}$. The animals were then separated in three groups: G1 was composed of 37 calves with below average ADG; G2 was composed of 35 animals with below average ADG; and G3 was composed of 15 animals with above average ADG. On day zero animals in G1 were treated with $1.17 \mathrm{mg} \mathrm{Kg}^{-1}$ of diminazene diaceturate and $6.7 \mathrm{mg} \mathrm{Kg}^{-1}$ of oxytetracycline; those in $\mathrm{G} 2$ were treated with $1.2 \mathrm{mg} \mathrm{Kg}^{-1}$ of imidocarb dipropionate; and those in G3 were not treated. The animals were then monitored daily for the onset of disease, and on days 15 and 34 they were weighed and had their blood harvested. Animals in G1 had the better overall ADG $\left(0.613 \mathrm{Kg} \mathrm{day}^{-1}\right)$ $(\mathrm{P}<0.05)$, with no clinical cases during the experiment. The performance in G2 was moderate, not differing from either $\mathrm{G} 1$ or $\mathrm{G} 3$ (mean $\mathrm{ADG}=0.528 \mathrm{Kg} \mathrm{day}^{-1}$ ), however, this group had two clinical cases of anaplasmosis during the experiment. Animals in G3 had the worst performance, considering ADG $\left(0.343 \mathrm{Kg} \mathrm{day}^{-1}\right)$. When total weight gain per animal is compared for the study period (35 days), those in G1 gained an average of $20.851 \mathrm{Kg}$, followed by animals in $\mathrm{G} 2$ with $17.957 \mathrm{Kg}$, and then animals in G3 with $11.667 \mathrm{Kg}$. These results show that a low dose, agent specific (G1) drug protocol will considerably reduce the detrimental effects of subclinical tick borne diseases in the post weaning period and can be recommended as a rearing tool for calves destined for early slaughter.

Key words: Anaplasma marginale, Babesia spp., cattle, chemoprophylaxis, weight gain
\end{abstract}

\section{Resumo}

No presente estudo foram utilizados novilhos da raça Aberdeen Angus remanescentes de um de surto de babesiose e anaplasmose, expostos a infestações por carrapatos Rhipicephalus (Boophilus) microplus. No dia zero, o lote de 87 novilhos pesando em média 223,46 Kg, apresentava GMD de peso vivo de $0,258 \mathrm{Kg}$ por dia nos últimos 34 dias. O lote foi dividido em 3 grupos: G1, 37 novilhos com GMD abaixo da média; G2, 35 novilhos com GMD abaixo da média; G3, 15 novilhos com GMD acima da média geral do lote. Os novilhos do G1 foram submetidos à quimioprofilaxia com uso de $1,17 \mathrm{mg} \mathrm{Kg}^{-1}$ de diaceturato de diminazeno e $6,7 \mathrm{mg} \mathrm{Kg}^{-1}$ de oxitetraciclina. Os novilhos do $\mathrm{G} 2$ foram submetidos à

\footnotetext{
Médicos Veterinários, Profs. Drs., Dept ${ }^{\circ}$ de Veterinária Preventiva, Universidade Federal de Pelotas, UFPel, Pelotas, RS, Brasil. E-mail: silva.sergios10@gmail.com; fagondee@gmail.com; meireles@ufpel.edu.br; leandro.nizoli@gmail.com

2 Médicos Veterinários, Discentes do Programa de Pós-Graduação em Veterinária, UFPel, Pelotas, RS, Brasil. E-mail: iurihrs@ hotmail.com; samuelrf@gmail.com

3 Médicos Veterinários, Dept ${ }^{\circ}$ Técnico, Ourofino Agronegócios, Ourofino, Ribeirão Preto, SP, Brasil. E-mail: daniela.miyasaka@ ourofino.com; marcus.rezende@ourofino.com

* Author for correspondence
} 
quimioprofilaxia com o uso de $1,2 \mathrm{mg} \mathrm{Kg}^{-1}$ de dipropionato de imidocarb. Os animais do $\mathrm{G} 3$ não foram medicados. O G1 obteve o melhor desempenho de ganho de peso no período $\left(0,613 \mathrm{Kg} \mathrm{dia}^{-1}\right)(\mathrm{P}<0,05)$ e não apresentou nenhum caso clínico da doença durante o experimento. O protocolo quimioprofilático do G2 teve desempenho mediano, sem diferença dos demais grupos $\left(0,528 \mathrm{Kg} \mathrm{dia}^{-1}\right)$ e o $\mathrm{G} 3$ teve o pior desempenho $\left(0,343 \mathrm{Kg} \mathrm{dia}^{-1}\right)$, porém ocorreram 2 quadros clínicos de anaplasmose no final do experimento no G2. Na comparação do desempenho no ganho de peso total por animal no período, o G3 (Controle) obteve 11,667 Kg, O G2 obteve 17,957 Kg e o G1 obteve 20,851 Kg. O protocolo quimioprofilático a base de diaceturato de diminazeno e oxitetraciclina demonstrou-se uma ferramenta importante para aplacar os efeitos deletérios da TPB subclínica no período pós desmame, podendo ser recomendada como ferramenta de melhoria de desempenho em categorias jovens de bovinos destinados ao abate precoce.

Palavras-chave: Anaplasma marginale, Babesia spp, bovinos, ganho de peso, quimioprofiaxia

\section{Introduction}

Tick borne diseases (TBD) caused by hemoparasites (Babesia bigemina and/or Babesia bovis), and bacteria (Anaplasma marginale), are responsible for the most prevalent and economically important livestock disease of all tick-borne ailments (SUAREZ; NOH, 2011). Babesiosis, is usually transmitted by the Rhipicephalus (Boophilus) microplus tick (DALGLIESH; STEWART, 1983), while Anaplasmosis can also be transmitted by blood sucking flies (GUGLIELMONE, 1995; KESSLER, 2001).

Favorable climate conditions are required for the development of the tick vector, and enzootic instability will occur when populations fluctuate throughout the year. Some Brazilian regions are considered unstable, specifically the southern part of Rio Grande do Sul (RS), the southernmost state in Brazil. In winter, low temperatures and frequent frosts kill most tick larvae, reducing cattle infestation. Dry, hot summers will also hamper the tick's development cycle. Cattle born in these regions may not be exposed to the vector or TBD agents, resulting in a lack of immunity. Osaki et al. (2002) showed that passive immunity will wane in time, and be at its lowest when the calves reach five months of age. This effect increases the chances of subclinical outbreaks once tick population increase. Calves will suffer with low PCV and reduced weight gain, without necessarily showing significant signs that would trigger veterinary intervention (NIZOLI et al., 2012).
Conventional treatment, according to Vial and Gorenflot (2006), is $3.5 \mathrm{mg} \mathrm{Kg}^{-1}$ diminazene diaceturate for babesiosis. Anaplasmosis can be treated with $20 \mathrm{mg} \mathrm{Kg}^{-1}$ of long-acting oxytetracycline (FACURY-FILHO et al., 2012). Double effect drugs, such as imidocarb dipropionate can also be used in doses from 1 to $3 \mathrm{mg} \mathrm{Kg}^{-1}$ (VIAL; GORENFLOT, 2006). In clinical cases of anaplasmosis, even after treatment, animals will become chronic carriers of the agent, and at greater risk of reoccurrence (FELSHEIM et al., 2010). In 2012, Nizoli et al. (2012) showed that reduced doses of an association of oxytetracycline and diminazene diaceturate were able to minimize the production losses associated with subclinical TBD. However, these authors did not assess the use of double effect drugs for the same outcome.

The present study assesses the use of an association protocol (oxytetracycline and diminazene diaceturate) and single drug protocol (imidocarb dipropionate) on subclinical babesiosis and anaplasmosis, especially on the weight gain of recently weaned calves, in an enzootic instable environment.

\section{Material and Methods}

In this study, 87 recently weaned calves (from a group of 297) were identified with unique earrings and ear tattoos. All calves, predominantly of the Angus breed, were kept under field conditions, grazing freely with no additional feed but mineral 
salt (ad libitum). Ages ranged from six to nine months, with an average weight of $223.46 \mathrm{Kg}$ ( \pm 43.12). The assay was conducted during a period of varying tick infestations, from April to June 2012, representing an environment for natural TBD challenge. The study was conducted in a rural setting in the municipality of Capão do Leão, RS, Brazil ( $31^{\circ} 53^{\prime} \mathrm{S}$ and $\left.52^{\circ} 38^{\prime} \mathrm{W}\right)$

All the animals were weighed on an electronic scale (Tru-Test XR3000 ${ }^{\circledR}$ ) on days -34 and zero, and the average daily weight gain (ADG) prior to the start of the experiment was assessed. The overall average was $0.258 \mathrm{Kg}$ a day. After the second weighing (day zero), those animals with an ADG below the mean were separated to compose the treated groups: $\mathrm{G} 1(\mathrm{n}=37)$ and $\mathrm{G} 2(\mathrm{n}=35)$. Among those with above average ADG, 15 were chosen for the mock treated control group: G3.

On day zero, animals in G1 were treated with a deep intra-muscular (IM) injection of diminazene diaceturate (1.17 $\left.\mathrm{mg} \mathrm{Kg}^{-1}\right)$ and oxytetracycline (6.7 $\mathrm{mg} \mathrm{Kg}^{-1}$ ), using one third of the recommended treatment dose, as described by Nizoli et al. (2012). Animals in G2 were treated with an IM injection of imidocarb dipropionate (1.2 $\mathrm{mg} \mathrm{Kg}^{-1}$ ) as recommended for prophylactic purposes (VIAL; GORENFLOT, 2006). Animals in G3 were mock treated with IM sterile saline.

Faeces were collected from all animals in day zero to assess gastrointestinal parasite burdens through the modified Gordon \& Whitlock method (UENO; GONÇALVES, 1998). This was used as an internal control to discard the possibility of interference from gastrointestinal parasites in the assessed parameters. Nonetheless, all animals were treated with $34 \%$ nitroxynil $\left(1 \mathrm{~mL} 50 \mathrm{Kg}^{-1}\right)$.

The calves in all three groups were maintained under field conditions with ad libitum mineral supplementation, separated from other animals, and submitted to daily inspections regarding general health and tick infestations. Commercial products used in this study were: Imizol $\mathbb{R}^{4}$ (imidocarb dipropionate at $\left.120 \mathrm{mg} \mathrm{mL} \mathrm{mL}^{-1}\right)$; Pirofort $\AA^{5}$ (diminazene diaceturate at $70 \mathrm{mg} \mathrm{mL}^{-1}$ ); and Ourotetra Plus LA ${ }^{6}{ }^{6}$ (oxytetracycline at $200 \mathrm{mg}$ $\mathrm{mL}^{-1}$ and diclofenac sodium at $10 \mathrm{mg} \mathrm{mL}^{-1}$ ).

Blood samples were harvested, with and without anticoagulant, on days zero, 15, and 34 . The samples were maintained in isothermal boxes, and immediately sent for downstream processing in the Laboratório de Doenças Parasitárias (LADOPAR) of the Faculdade de Veterinária UFPel. Blood samples were used to assess packed cell volume (PCV). Samples with PCVs lower than $25 \%$ were also used to produce stained smears in order to assess Babesia and Anaplasma burdens. Sera were separated and used in an indirect immunofluorescence assay against $B$. bovis, $B$. bigemina (VIDOTTO et al., 1997), and $A$. marginale (MARANA et al., 2006).

All results were analyzed in the Statistix 9 software. The ADG were compared using the Kruskal-Wallis test. PCV were compared using ANOVA followed by the Tukey test. The correlation between PCV and ADG was assessed through the Spearman test.

\section{Results}

Serology revealed that $55 \%$ of the animals in the study population were positive for $A$. marginale, $45.9 \%$ for B. bigemina, and $4 \%$ for B. bovis, by the end of the assay. Between days zero and 34, 15 animals seroconverted for $A$. marginale, and nine for $B$. bigemna. This seroconversion was not associated with treatment $(\mathrm{P}>0.05)$, occurring in all three groups. During the routine inspections, young tick instars were observed in calves from all groups, confirming the risk of infection/reinfection. Likewise, gastro-intestinal parasite infestations were relatively low (mean EPG; G1= $150 \pm 199$;

\footnotetext{
4 MSD Saúde Animal.

5 Ourofino Saúde animal.

6 Ourofino Saúde animal.
} 
$\mathrm{G} 2=206 \pm 281 ; \mathrm{G} 3=167 \pm 216)$, with no difference among groups $(\mathrm{P}>0.05)$.

The ADG, calculated through the weighing of the animals on days zero, 15 , and 34 , are expressed on table 1. In the assessment considering the difference from day -34 to zero, the ADG of G3 was higher than that of the other groups, as predicted by the proposed methodology. Between days zero and 15, G1 had the grater ADG $(\mathrm{p}<0.05)$. No difference was observed among G2 and G3 in these first 15 days. Likewise, G1 was the only group that did not register a reduction in ADG in this period. Between days 15 and 34, there was no difference in weight gain among groups. The complete ADG data can be observed in table 1. Considering the total gain in the study period (from day zero to 34), G1 had a greater ADG than the control, but no other differences were observed. Further data regarding the total gain during the study period can be seen on table 2 .

Table 1. Mean ( \pm Standard Deviation) ADG observed on days zero, 15, and 34, of calves treated with different chemoprophylactic protocols against bovine TBDs in the municipality of Capão do Leão-RS.

\begin{tabular}{cccc}
\hline Group & \multicolumn{1}{c}{ Day 0 } & \multicolumn{1}{c}{ Day 15 } & \multicolumn{1}{c}{ Day 34 } \\
\hline G 1 & $0.138 \pm 0.170 \mathrm{Kg} \mathrm{cA}$ & $0.326 \pm 0.418 \mathrm{Kg} \mathrm{bA}$ & $0.814 \pm 0.334 \mathrm{Kg} \mathrm{aA}$ \\
G 2 & $0.151 \pm 0.156 \mathrm{Kg} \mathrm{bA}$ & $0.070 \pm 0.467 \mathrm{Kg} \mathrm{bAB}$ & $0.849 \pm 0.375 \mathrm{Kg} \mathrm{aA}$ \\
G 3 & $0.807 \pm 0.132 \mathrm{Kg} \mathrm{aB}$ & $-0.190 \pm 0.418 \mathrm{Kg} \mathrm{bB}$ & $0.717 \pm 0.598 \mathrm{Kg} \mathrm{aA}$ \\
\hline
\end{tabular}

Different upper case letters represent statistically different results on the column; Kruskal-Wallis $(\mathrm{p}<0.05)$; Different lower case letters represent difference on the line; Tukey $(\mathrm{p}<0.05)$.

G1- diminazene diaceturate and oxytetracycline; G2 - imidocarb dipropionate; G3 - Control.

Table 2. Mean ADG for the entire experimental period, of calves treated with different chemoprophylactic protocols against bovine TBDs in the municipality of Capão do Leão-RS.

\begin{tabular}{ccccc}
\hline Group & ADG & Lowest ADG & Highest ADG & $\begin{array}{c}\text { Mean individual } \\
\text { weight gain }\end{array}$ \\
\hline G 1 & $0.613 \pm 0.260 \mathrm{Kg} \mathrm{A}$ & $0.118 \mathrm{Kg}$ & $1.221 \mathrm{Kg}$ & $20.851 \mathrm{Kg} \mathrm{A}$ \\
G 2 & $0.528 \pm 0.209 \mathrm{Kg} \mathrm{AB}$ & $-0.029 \mathrm{Kg}$ & $0.912 \mathrm{Kg}$ & $17.957 \mathrm{Kg} \mathrm{AB}$ \\
G 3 & $0.343 \pm 0.309 \mathrm{Kg} \mathrm{B}$ & $-0.088 \mathrm{Kg}$ & $0.853 \mathrm{Kg}$ & $11.667 \mathrm{Kg} \mathrm{B}$ \\
\hline
\end{tabular}

Different letters represent statistically different results on the column; Kruskal-Wallis $(\mathrm{p}<0.05)$.

G1- diminazene diaceturate and oxytetracycline; G2 - imidocarb dipropionate; G3 - Control.

The PCV did not seem to be associated with the ADG in this assay, and remained within limits considered normal throughout the study in all animals (except the two animals in G2 that became clinically ill). These two animals had PCVs of 20 and $18 \%$, and characteristic signs of anaplasmosis, which was confirmed by the stained blood smears. Cell infection rates of $40 \%$ were observed in both cases, confirming the clinical disease caused by Anaplasma marginale. Complete results regarding the PCV can be seen on table 3 . 
Table 3. Mean ( \pm Standard Deviation) PCV observed on days zero, 15, and 34, of calves treated with different chemoprophylactic protocols against bovine TBDs in the municipality of Capão do Leão-RS.

\begin{tabular}{cccc}
\hline Group & Day 0 & Day 15 & Day 34 \\
\hline G 1 & $34.67 \pm 5.16 \mathrm{aAB}$ & $35.67 \pm 3.23 \mathrm{aA}$ & $35.53 \pm 2.46 \mathrm{aA}$ \\
G 2 & $33.39 \pm 5.25 \mathrm{bB}$ & $35.67 \pm 2.91 \mathrm{aA}$ & $32.45 \pm 2.48 \mathrm{bB}$ \\
G 3 & $37.13 \pm 4.12 \mathrm{aA}$ & $32.60 \pm 2.95 \mathrm{bB}$ & $35.46 \pm 3.11 \mathrm{abA}$ \\
\hline
\end{tabular}

Different upper case letters represent statistically different results on the column; lower case represent difference on the line; Kruskal-Wallis $(\mathrm{p}<0.05)$.

G1 - diminazene diaceturate and oxytetracycline; G2 - imidocarb dipropionate; G3 - Control.

\section{Discussion}

The results generated in the present study suggest that a combination of diminazene diaceturate and oxytetracycline, at 1.17 and 6.7 mg. $\mathrm{Kg}^{-1}$, respectively, can be used to minimize the losses associated with subclinical babesiosis and/or anaplasmosis, during and after weaning. Furthermore, this association seems to have a better effect than dual purpose drugs (imidocarb dipropionate) during this high risk period. Losses associated with subclinical TBDs are difficult to assess, however, some authors suggest that, in the area of this study alone, they may reach up to $1,623,000$ dollars in deaths, not considering weight loss, medical care, and other possible expenses (ALMEIDA et al., 2006). Grisi et al. (2002) estimate that the disease causes over 500 milion in losses each year, just in Brazil. In our study the difference in weight gain throughout was of $270 \mathrm{~g}$ a day in favor of those treated with the combination (613 g.day $\left.{ }^{-1}\right)$ compared to those untreated (343 g.day $\left.^{-1}\right)$ (Table 2). This difference represents a total of 9.18 $\mathrm{Kg}$ during the 34 days of the study, when a new application of the drugs would be recommended in order to maintain the prophylactic effects (NIZOLI et al., 2012). Considering the better weight gain of the control group prior to the star of the study (from day -34 to day zero), the productive and economic gains may be even larger, and randomized studies should be conducted to confirm this. Likewise, when animals treated with the combination are compared to those treated with a dual purpose drug (528 g.day $^{-1}$ ), the difference is of 85 g.day $^{-1}$ per animal in favor of the prior.
In a previous study, Nizoli et al. (2012) showed a similar effect of the association of oxytetracyclin and diminazene diaceturate, however, the experimental design did not allow the comparison of the treated groups and the control, only the recovery of treated animals. Furthermore, that study did not assess intermediate dates or dual purpose drugs, PCV, and seroconversion. In our study the fluctuation in weight gain, characteristic of enzooticaly unstable settings, could be observed, evidenced by the decrease of this parameter by day 15 in groups G2 and G3.Iin G2, this may have occurred because imidocarb has a delayed effect on anaplasmosis.

The drugs used in this study are the most frequently applied by veterinarians in the treatment of bovine babesiosis and anaplasmosis (KUTTLER, 1980; TODOROVIC et al., 1973; VIAL; GORENFLOT, 2006). Nonetheless, some authors recommend the use of enrofloxacin for the treatment of anaplasmosis (FACURY-FILHO et al., 2012), but this drug has shown little effect in several studies (ATIF et al., 2012; COETZEE et al., 2006). While in Brazil the recommended dose against anaplasmosis is up to $20 \mathrm{mg} \mathrm{Kg}^{-1}$ of long acting oxytetracycline in a sigle application (FACURY-FILHO et al., 2012; SILVA et al., 2007), other countries use the drug in doses as low as $7 \mathrm{mg} \mathrm{Kg}^{-1}$ (ORTIZ et al., 2012). In this light, we believe that not only subclinical, but even mild cases of anaplosmosis could be treated with the dose used in this study $\left(6.7 \mathrm{mg} \mathrm{Kg}^{-1}\right)$, allowing full productive recuperation. Even if used in high doses, oxytetracycline and imidocarb diaceturate rarely eliminate Anaplasma completely, and cattle, once 
infected, will become lifelong carriers (COETZEE et al., 2005, 2006). Therefore, the use of high doses is not justified for prophylactic purposes.

Although the PCV did vary during this study, with significant differences among groups (Table 3), the mean values remained above $32 \%$ throughout, regardless of ADG or serological status, and these parameters were not correlated. The only exceptions were the two animals that suffered clinical anaplasmosis, with PCV counts of 20 and $18 \%$ on day 34 (both from G2). These results show that sublinical bovine babesiosis and anaplasmosis does not seem to have a significant effect on PCV, contrary to its considerable impact on productive parameters (NIZOLI et al., 2012).

The results obtained in this study confirm the enzootic instability of the region, as predicted by Guglielmone (1995). Another assay with cattle herds from the same region, with latitudes close to $32^{\circ} \mathrm{S}$, had also indicated the risk of outbreaks due to these factors (MARTINS et al., 1994).

The seroconversion of some animals, associated with the presence of young tick instars (larvae and nymphs) during inspection, suggest the transmission of TBDs in the herd during the experimental period, with no clinical cases in G1, indicating the advantage of the drug association in these settings. Animals that were positive to one or more TBD agents at the start of the experiment had a better outcome in the treated groups, reinforcing the potential of this rearing tool also in regions were the disease is endemic.

\section{Conclusions}

This study confirms the potential of prophylactic applications of diminazene diaceturate and oxytetracycline in diminishing the deleterious effects of subclinical babesiosis and anaplamosis in recently weaned calves. The association of these two agent specific drugs is more efficient than the use of a similar protocol based on a dual purpose drug (imidocarb dipropionate), avoiding clinical cases of anaplasmosis for, at least, 34 days. These results suggest that the chemoprophylactic protocol described herein should be adopted to increase the productivity of calves destined for early slaughter.

\section{Acknowledgments}

The authors thank professor Odilon Vidotto, of the Universidade Estadual de Londrina, for the serological analyses. We thank the manager of the Estância Capão Redondo, Mr. Virgílio Bahmann, for helping with the experimental conditions and animals. We thank the technical advisor from Ourofino, Mr. Rodrigo Jeske Dummer.

\section{References}

ALMEIDA, M. B.; TORTELLI, F. P.; RIET-CORREA, B.; SOARES, M. P.; FARIAS, N. A. R.; RIET-CORREA, F.; SCHILD, A. S. Tristeza parasitária bovina na região sul do Rio Grande do Sul: estudo retrospectivo de 19782005. Pesquisa Veterinária Brasileira, Seropédica, v. 26, n. 4, p. 237-242, 2006.

ATIF, F. A.; KHAN, M. S.; KHAN, M. A.; ASHRAF, M.; AVAIS, M. Chemoterapeutic efficacy of oxytetracicline, enrofloxacin and imidocarb for the elimination of persistent Anaplasma marginale infection in naturally infected Sahiwal cattle. Pakistan Journal of Zoology, Punjab, v. 44, n. 2, p. 449-456, 2012.

COETZEE, J. F.; APLEY, M. D.; KOCAN, K. M. Comparision of the efficacy of enrofloxacin, imidocarb and oxitetracycline for clearance of persistent Anaplasma marginale infections in cattle. Veterinary Therapeutics: Research in Applied Veterinary Medicine, Memphis v. 7 , n. 4, p. 347-360, 2006.

COETZEE, J. F.; APLEY, M. D.; KOCAN, K. M.; RURANGIRWA, F. R.; DONKERSGOED, J. V. Comparision of three oxytetracicline regimens for the treatment of persistent Anaplasma marginale infections in beef cattle. Veterinary Parasitology, Amsterdam, v. 127, n. 1, p. 61-73, 2005.

DALGLIESH, R. J.; STEWART, N. P. The use of tick transmission by Boophilus microplus to isolate pure strains of Babesia bovis, Babesia bigemina and Anaplasma marginale from cattle with mixed infections. Veterinary Parasitology, Amsterdam, v. 13, n. 4, p. 317323, 1983. 
FACURY-FILHO, E. J.; CARVALHO, A. U.; FERREIRA, P. M.; MOURA, M. F.; APOLINARIO, B. C.; SANTOS, L. P.; RIBEIRO, M. F. Effectiveness of enrofloxacin for the treatment of experimentally-induced bovine anaplasmosis. Revista Brasileira de Parasitologia Veterinaria, São Carlos, v. 21, n. 1, p. 32-36, 2012.

FELSHEIM, R. F.; CHÁVEZ, A. S. O.; PALMER, G. H.; CROSBY, L.; BARBET, A. F.; KURTTI, T. J.; MUNDERLOH, U. G. Transformation of Anaplasma marginale. Veterinary Parasitology, Amsterdam, v. 167, n. 2-4, p. 167-174, 2010.

GRISI, L.; MASSARD, C. L.; BORJA, G. E. M.; PEREIRA, J. B. Impacto econômico das principais ectoparasitoses em bovinos no Brasil. Hora Veterinária, Porto Alegre, v. 21, n. 125, p. 8-10, 2002.

GUGLIELMONE, A. A. Epidemiology of babesiosis and anaplasmosis in South and Central America. Veterinary Parasitology, Amsterdam, v. 57, n. 1-3, p. 109-119, 1995.

KESSLER, R. H. Considerações sobre a transmissão de Anaplasma marginale. Pesquisa Veterinária Brasileira, Seropédica, v. 21, n. 4, p. 177-179, 2001.

KUTTLER, K. L. Pharmacotherapeutics of drugs used in treatment of anaplasmosis and babesiosis. Journal of the American Veterinary Medical Association, Schaumburg, v. 176, n. 10, p. 1103-1108, 1980.

MARANA, E. R. M.; ALFIERI, A. A.; ANDRADE, G. M.; FREIRE, R. L.; GARCIA, J. L.; VIDOTTO, O. Comparação dos testes sorológicos de imunofluorescência indireta, conglutinação rápida, ELISA indireto e ELISA de competição para detecção de anticorpos contra Anaplasma marginale em soros de diferentes áreas enzoóticas. Semina: Ciências Agrárias, Londrina, v. 27, n. 4, p. 629-638, 2006.

MARTINS, J. R.; CORREA, B. L.; CERESER, V. H.; ARTECHE, C. C. P.; GUGLIELMONE, A. A. Some aspects of the epidemiology of Babesia bovis in Santana do Livramento, southern Brazil. Revista Brasileira de Parasitologia Veterinária, São Carlos, v. 3, n. 2, p. 7578, 1994.

NIZOLI, L. Q.; MARMITT, I. V. P.; BIEGELMEYER, P.; MOTTA, J. F.; SANTOS, T. R. B.; SILVA, S. S. Efeito quimioprofilático do diaceturado de diminazeno (Ganaseg ${ }^{\circledR}$ ) e oxitetraciclina (Talcin Max ${ }^{\circledR}$ ) contra a Tristeza Parasitária subclínica na melhoria do ganho de peso em novilhos precoces para abate. A Hora Veterinária, Porto Alegre, v. 31, n. 186, p. 17-20, 2012.
ORTIZ, E. F.; GERDTS, O. V.; PALENCIA, N. P.; PINEDA, A. M.; HURTADO, O. J. B. Therapeutic effect of an anaplsmicid and anti-protozoa product against the blood parasites of cattle. CES Medicina Veterinaria y Zootecnia, Bogotá, v. 7, n. 1, p. 33-48, 2012.

OSAKI, S. C.; VIDOTTO, O.; MARANNA, E. R. M.; VIDOTTO, M. C.; YOSHIHARA, E.; PACHECO, R. C.; IGARASHI, M.; MINHO, A. P. Ocorrência de anticorpos anti Babesia bovis e estudo sobre a infecção natural em bovinos da raça Nelore, na região de Umuarama, Paraná Brasil. Revista Brasileira de Parasitologia, São Carlos, v. 11, n. 2, p. 77-83, 2002.

SILVA, R. A.; CORRÊA, F. N.; BOTTEON, R. C. C. M.; BOTTEON, P. T. L. Infecção natural por hemoparasitos em bezerros submetidos à quimio-profilaxia aos 30 dias de idade. Revista Brasileira de Parasitologia Veterinária, São Carlos, v. 16, n. 3, p. 163-165, 2007.

SUAREZ, C. E.; NOH, S. Emerging perspectives in the research of bovine babesiosis and anaplasmosis. Veterinary Parasitology, Amsterdam, v. 180, n. 1-2, p. 109-125, 2011.

TODOROVIC, R. A.; VIZCAINO, D. V. M.; GONZALEZ, E. F.; ADAMS, L. G. Chemoprophylaxis (Imidocarb) against Babesia bigemina and Babesia argentina infections. The American Journal of Veterinary Research, Schaumburg, v. 34, n. 9, p. 1153-1161, 1973.

UENO, H.; GONÇALVES P. C. Manual para diagnóstico das helmintoses de ruminantes. 4. ed. Tokyo: Japan International Cooperation Agency, 1998. 143 p.

VIAL, H. J.; GORENFLOT, A. Chemotherapy against babesiosis. Veterinary Parasitology, Amsterdam, v. 138, n. 1, p. 147-160, 2006.

VIDOTTO, O.; ANDRADE, G. M.; AMARAL, C. H. S.; BARBOSA, C. S.; FREIRE, R. L.; ROCHA, M. A.; VIDOTTO, M. C.; SILVA, S. S. Frequência de anticorpos contra Babesia bigemina, B. bovis e Anaplasma marginale em rebanhos de bovinos leiteiros da região de Londrina, Paraná. Arquivo Brasileiro de Medicina Veterinária e Zootecnia, Belo Horizonte, v. 49, n. 5, p. 655-659, 1997. 
